\title{
Performance requirements to ensure the efficiency of bacteria-based self-healing concrete
}

\author{
EIRINI TZIVILOGLOU ${ }^{*}$, VIRGINIE WIKTOR $^{\dagger}$, HENK M. JONKERS $^{\dagger}$ AND ERIK \\ SCHLANGEN ${ }^{\dagger}$ \\ *Delft University of Technology \\ Delft, The Netherlands \\ e-mail: e.tziviloglou@tudelft.nl \\ $\dagger$ Delft University of Technology \\ Delft, The Netherlands \\ e-mail:w.a.c.wiktor@tudelft.nl \\ $\dagger$ Delft University of Technology \\ Delft, The Netherlands \\ e-mail: h.m.jonkers@tudelft.nl \\ $\dagger$ Delft University of Technology \\ Delft, The Netherlands \\ e-mail: erik.schlangen@tudelft.nl
}

Key words: bacteria, self-healing concrete, crack sealing, efficiency requirements

\begin{abstract}
Self-healing concrete has been the subject of great scientific interest over the last ten years. Various research groups worldwide have been working on different healing agent concepts, with bacteria-based healing agents being one of the most popular. Bacterial spores together with organic mineral precursor compounds are immobilized and protected in capsules. Once a crack is created, the bacterial spores turn from a dormant to an active state and start to metabolize the organic compounds, resulting in the production of calcium carbonate crystals. Those crystal formations are able to bridge the open cracks. Many studies have proven the enhanced healing performance of bacteria-based self-healing cementitious materials in comparison to the ordinary ones. However, they do not explicitly designate which performance conditions should be satisfied in order to verify the functionality of the embedded healing agent. This study presents and explains why there are three requirements needed to ensure the performance of a bacteria-based healing agent. Those requirements are the presence of mineral formation inside the crack, the reduced crack permeability and the evidence of bacterial activity in the mortar. In this study, the requirements are studied on mortar specimens through: i) microscopic observations on crystals found inside the cracks, ii) crack water permeability tests and iii) oxygen concentration measurements.
\end{abstract}

\section{INTRODUCTION}

Self-healing concrete has received a lot of attention recently. The idea behind the concept is rather simple, however, it can prove to be very beneficial throughout the life time of a concrete structure. Cracks are able to heal without external human intervention, only by the activation of the healing agent, which later is released and bridges the crack openings. The nature of the healing agent can vary from synthetic polymeric to bacteria-based healing agent, embedded in protective capsules or 
dispersed randomly in the concrete matrix.

The bacteria-based self-healing agent used in this study consisted of alkaliphilic bacterial spores and organic mineral precursor compounds incorporated into lightweight aggregates, acting as protective capsules. Once a crack appears, the bacterial spores, which until then were dormant, turn to an active state after activation by ingress of water in the crack and start to metabolize the organic compounds. The result of the bacterial metabolic activity is the production of calcium carbonate $\left(\mathrm{CaCO}_{3}\right)$ crystals. The crystals start to grow inside the crack and ultimately they bridge it.

Previous researches have showed the enhanced performance of bacteria-based selfhealing cementitious materials in comparison to the conventional ones. However, the performance conditions to be satisfied, in order to verify the functionality of the bacterial-based healing agent have not been designated. For example, Stucktath et al. [1] quantified the amount of $\mathrm{CaCO}_{3}$ precipitation in bacteria-based self-healing mortar through image analysis (photographic pictures), thermal analysis and Scanning Electron Microscopy (SEM). They did not, though, include in their research the proof of either bacterial activity or recovery of watertightness after cracking and healing. On the other hand, Wiktor and Jonkers [2] evaluated the efficiency of the bacteria-based healing agent incorporated in lightweight aggregates through visual crack closure (stereomicroscopic pictures) and oxygen consumption measurements, but there was no data on the recovery of water-tightness after healing. The same for Sierra Beltran et al. [3], who characterized the bio-based self-healing agent in repair mortar through visual crack closure (Environmental Scanning Electron Microscopy, ESEM) and oxygen consumption measurements. Moreover, Wang et al. [4] investigated the efficiency of bacteria-based healing agent immobilized either in silica gel or in polyurethane through strength regain and water permeability tests in cracked and healed specimens. In their study, they also included SEM on $\mathrm{CaCO}_{3}$ precipitates and bacterial activity investigation via conductivity measurements. Yet, the tests were conducted in silica gel and polyurethane foam with bacteria but not incorporated in mortar specimens.

This study presents the three performance requirements needed to designate the efficiency of a bacteria-based healing agent incorporated in concrete/mortar; namely, the presence of mineral formation inside the crack, the reduced crack permeability and the evidence of bacterial activity in the mortar (Fig.1). In the current research, the requirements are studied on mortar prismatic specimens through: i) microscopic observations on crystal formations, ii) permeability tests via water flow on cracked mortar specimens before and after healing and iii) oxygen concentration measurements on the mortar specimen.

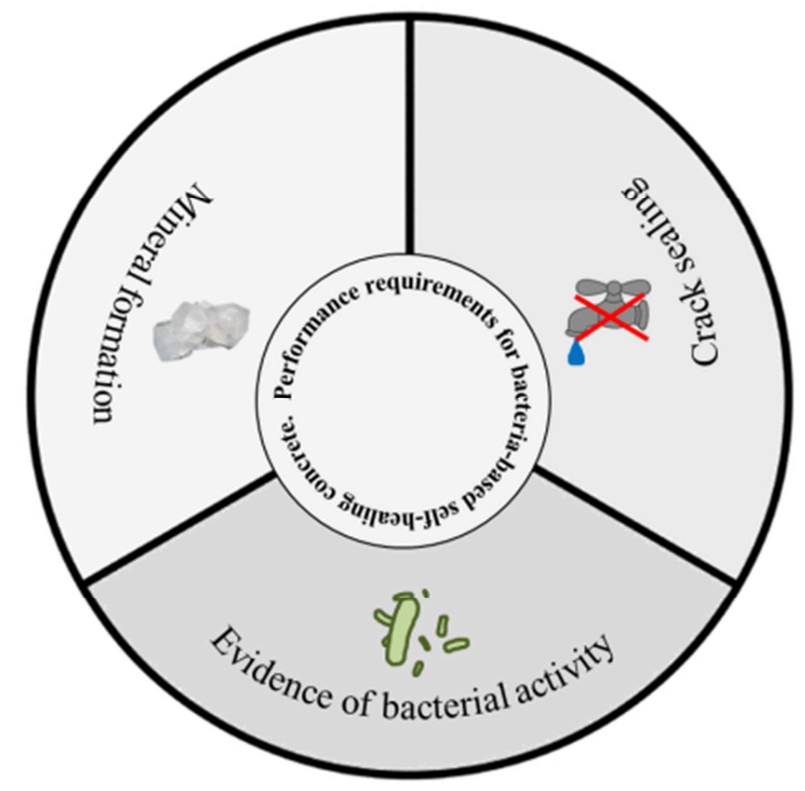

Fig. 1 The three performance requirements to ensure the desired performance of a bacteria-based self-healing agent.

\section{MATERIALS AND METHODS}

\subsection{Preparation of the healing agent}

The bio-based healing agent consisted of spores derived from alkaliphilic bacteria of the genus Bacillus and organic precursor mineral compounds. The healing agent was embedded in expanded clay particles, Liapor 1-4 mm (Liapor, GmbH Germany) via vacuum 
impregnation with calcium lactate (nutrient for the bacteria), yeast extract (vitamins for bacteria) and bacterial spores suspension. Specifically, the impregnation solution contained: calcium lactate- $(200 \mathrm{~g} / \mathrm{L})$, yeast extract- $(4 \mathrm{~g} / \mathrm{L})$, bacterial spores $\left(10^{8}\right.$ spores $\left./ \mathrm{L}\right)$. After impregnation and drying (at $20^{\circ} \mathrm{C}$ and $60 \% \mathrm{RH}$ ) of the lightweight particles increase their initial dry weight by approximately $10 \%$.

\subsection{Preparation of mortar specimens}

Prismatic mortar specimens $(40 \mathrm{~mm} \times 40$ $\mathrm{mm} \times 160 \mathrm{~mm}$ ) modified with a $5 \mathrm{~mm}$ hole in their middle were cast, as can be seen in [5]. The specimens contained also 2 steels wires $(\varnothing$ $1 \mathrm{~mm}$ ) at a distance of $10 \mathrm{~mm}$ from the bottom, which acted as reinforcement. The mix composition is shown in Table 1.

Table 1: Mix design used for bacteria-based mortar prisms

\begin{tabular}{cc}
\hline Material & $\begin{array}{c}\text { Amount } \\
\left(\mathrm{kg} / \mathrm{m}^{3}\right)\end{array}$ \\
\hline CEM I 42.5 N & 463 \\
\hline Water & 231.5 \\
\hline Sand $(0.125-1 \mathrm{~mm})$ & 810 \\
\hline Liapor $(1-4 \mathrm{~mm})$ & $283^{*}$ \\
\hline
\end{tabular}

$* 26 \mathrm{~g}$ from the $283 \mathrm{~g}$ of Liapor particles is the healing agent.

\subsection{Damage introduction and healing treatment}

The cracks were introduced in the specimens at the age of 28 days by 3-pointbending. The reinforcement helped loading the specimens until the formation of a stable and rather large crack $(350 \mu \mathrm{m})$, without being fractured completely into two parts. The exact procedure of loading-unloading is described in [6]. After the crack formation, the specimens were subjected to wet-dry cycles for 28 days. The specimens were placed on spacers in plastic containers. Each cycle lasted 12 hours. The container was kept open to the atmosphere at standard room temperature $\left(20 \pm 2{ }^{\circ} \mathrm{C}\right)$ with $60 \pm 10 \%$ RH.

\subsection{Microscopic investigation}

For the investigation of the healing product formed inside the crack during the healing treatment, the prisms were separated in two parts, so that both crack surfaces were exposed. The morphology of the precipitates was investigated by examination of the crack surface via ESEM equipped with Energy Dispersive X-ray spectrometer (EDS).

\subsection{Crack permeability test via water flow}

The crack permeability test was performed on triplicates before and after the 28-days of healing treatment on different specimens. Before the test, one of the two end-sides (40 $\mathrm{mm} \times 40 \mathrm{~mm}$ ) of the sample was covered with an insulating layer to prevent water passage. The middle hole of the specimen was connected to a water column of $500 \mathrm{~mm}$ through the other end side. Through a plastic tube the water passed from the water-column in the $5 \mathrm{~mm}$-hole and leaked out of the crack. The dripping water was falling in a container placed on an electronic scale. A computer connected to the scale was recording the experimental data, i.e. the water weight and the time. The set-up can be found in $[5,6]$.

\subsection{Oxygen consumption measurements}

As mentioned above, dormant bacterial spores are activated by ingress of water in the crack. Then, the active bacteria cells convert the calcium lactate $\left(\mathrm{CaC}_{6} \mathrm{H}_{10} \mathrm{O}_{6}\right)$, present in the healing agent to $\mathrm{CaCO}_{3}$ (1) by using oxygen [2].

$$
\mathrm{CaC}_{6} \mathrm{H}_{10} \mathrm{O}_{6}+6 \mathrm{O}_{2} \stackrel{\text { bacteria }}{\longrightarrow} \mathrm{CaCO}_{3}+5 \mathrm{CO}_{2}+5 \mathrm{H}_{2} \mathrm{O} \text { (1) }
$$

Therefore, oxygen concentration measurements on samples submerged in carbonate-bicarbonate buffer $(0.1 \mathrm{M} \mathrm{pH}=10.5)$ is the tool to evaluate bacterial activity in mortar. The buffer was used instead of water, in order to keep the $\mathrm{pH}$ stable throughout the experiment and to mimic the $\mathrm{pH}$ found in a concrete crack. For this test micro-sensor type Oxy50M (Presens, Germany) was used. The micro-sensor, fixed to a motorized micromanipulator on the vertical axis, was 
measuring the oxygen concentration in vertical steps of $50 \mu \mathrm{m}$ from $5 \mathrm{~mm}$ above, down to specimen's surface, placed in a tank filled with the buffer at $20 \pm 2{ }^{\circ} \mathrm{C}$. Thus, oxygen microprofile measurements were obtained.

\section{RESULTS}

The EDS analysis on the crystalline formations indicated high peaks of $\mathrm{Ca}, \mathrm{C}$ and $\mathrm{O}$, which suggested that indeed $\mathrm{CaCO}_{3}$ was present (Fig.2). ESEM images (Fig. 3) showed that the main crystal shapes that were found in the cracks were cubic or asymmetric rhombohedral, possibly polymorphs of $\mathrm{CaCO}_{3}$. In some cases, small elongated cavities $(\sim 5 \mu \mathrm{m}$ long) were found on the surface of the crystals, as seen in Fig. 3. Those cavities resemble the bacterial imprints found in microbially induced $\mathrm{CaCO}_{3}$ described also in other studies $[7,8]$.

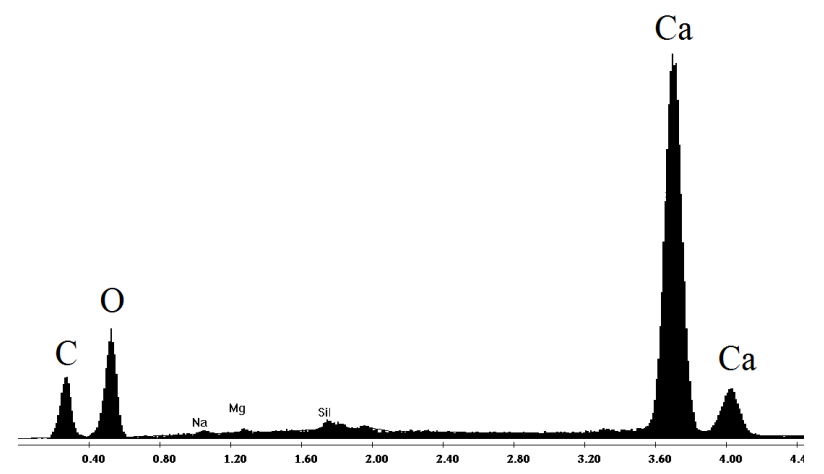

Fig. 2 EDS Analysis on crystals found inside the healed cracks.

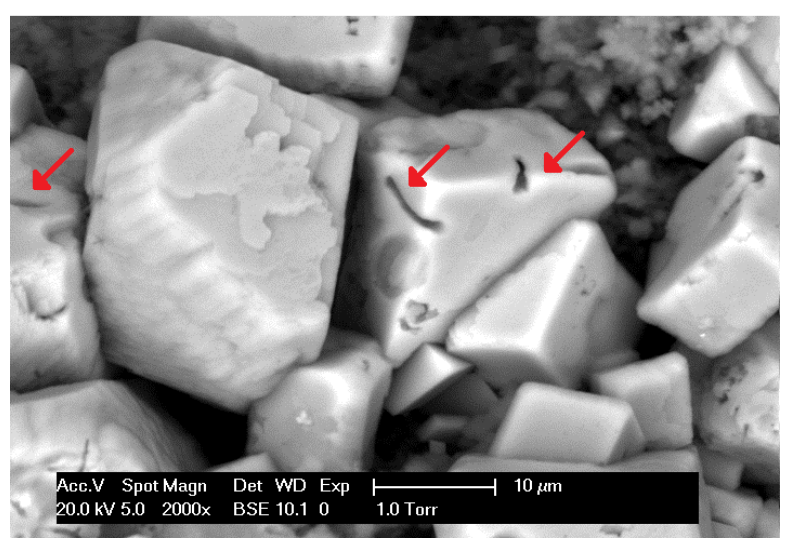

Fig. 3 ESEM image of precipitates that are found on the surface of the crack after the healing treatment. The arrows indicate the cavities (probably bacteria imprints) on the $\mathrm{CaCO}_{3}$ precipitates.

The results of the crack permeability test via water flow are shown in Fig. 4. It was observed that the leakage of the water out of the cracks was significantly lower for the healed specimens than for the unhealed ones.

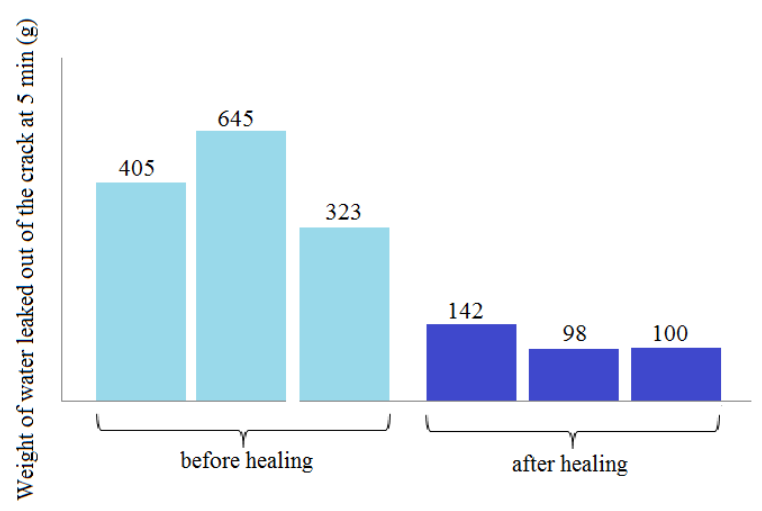

Fig. 4 Results from crack permeability test before and after healing on specimens with healing agent.

After the completion of test the recovery of water-tightness (RWT) was calculated. The calculation is shown in (2).

$R W T=\frac{W_{n-h}(5)-W_{h}(5)}{W_{n-h}(5)} \times 100$

Where:

$\mathrm{W}_{\mathrm{n}-\mathrm{h}}(5)$ : The average (out of three specimens) weight of water that has leaked through the specimen's unhealed crack after 5 $\min$.

$\mathrm{W}_{\mathrm{h}}(5)$ : The average (out of three specimens) weight of water that has leaked through the specimen's healed crack after 5 min.

The RWT after 28 days of healing treatment was $75 \%$.

As a comparison to the bacterial specimens, the same permeability experiment was repeated on samples without healing agent. The results (Fig. 5) showed that the sealing percentage after the healing treatment was significantly less than in bacterial samples. The RWT after 28 days of healing treatment was $24 \%$ for samples without healing agent. 


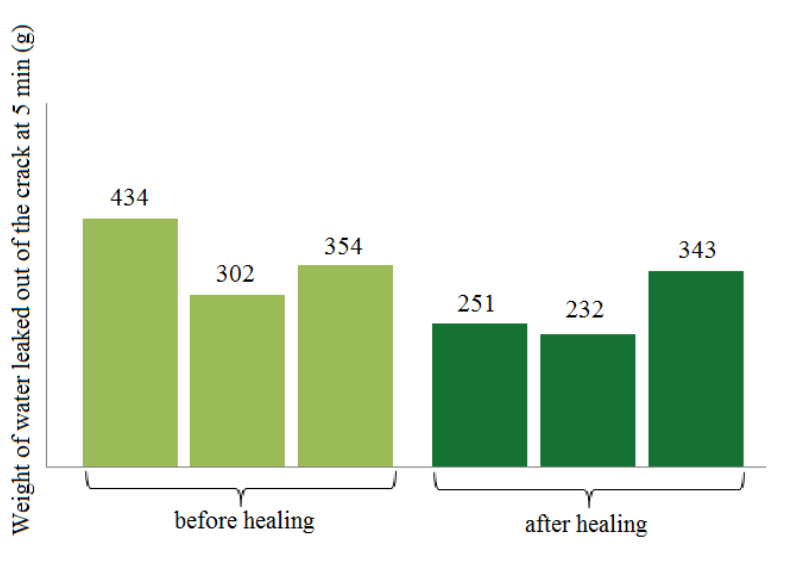

Fig. 5 Results from crack permeability test before and after healing on specimens without healing agent.

The oxygen profile measurements showed that oxygen concentration was rather constant up to a distance of approximately 1000-2000 $\mu \mathrm{m}$ from the surface of the bacterial specimen, while decreased further towards the surface. The range of oxygen consumption varied depending on the time of submersion. Fig. 6 shows the oxygen consumption at five different time intervals (after 0,60, 120, 160 and 220 hours of submersion). The consumption was almost zero right after the submersion and increased gradually until its maximum value at $160 \mathrm{~h}(25 \mu \mathrm{M}$ oxygen concentration decrease), after which it started to decrease until it became zero again (at 220 h).

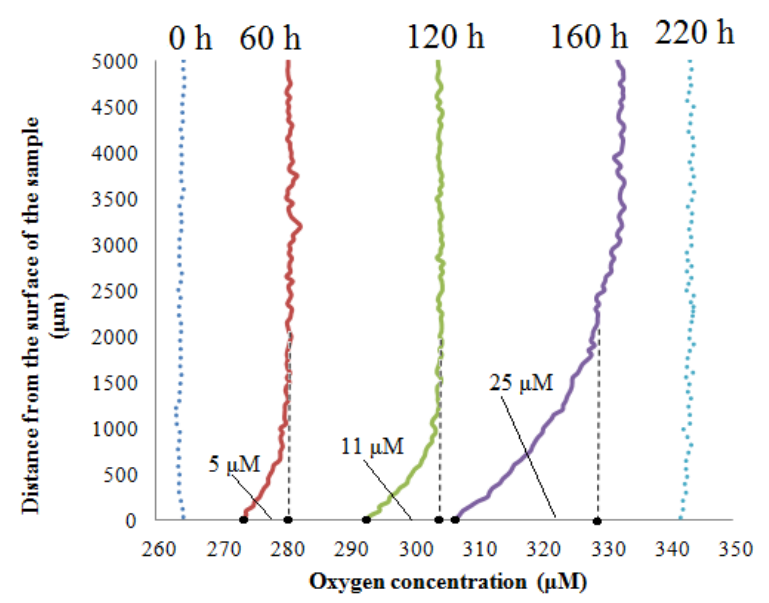

Fig. 6 Oxygen profiles on a bacteria-based mortar sample at certain time after submersion in buffer $(\mathrm{pH}=10.5)$.

In addition, it must be mentioned that the same method to investigate the existence of bacterial activity was applied in control specimens (without healing agent). In this study, as well as in other similar ones $[2,3,6]$ the results showed that there was no oxygen consumption for the samples without the bacteria-based healing agent.

\section{DISCUSSION}

The results revealed that each separate experimental part of the study gave evidence that indeed the bacteria-based self-healing system in mortar worked as expected. Specifically, there were $\mathrm{CaCO}_{3}$ formations inside the crack, the water permeability of the crack decreased after healing (the recovery of water-tightness was $75 \%$ ) and there was oxygen consumption near the surface of the specimen when submerged in buffer solution with $\mathrm{pH}=10.5$. Nevertheless, it is important to mention that the specific healing agent needs specific environmental conditions in the area of the crack in order to work as efficiently as possible. Those are: i) temperature approximately $18-25^{\circ} \mathrm{C}$, ii) $\mathrm{pH}=8.5-11.0$, iii) $\mathrm{RH}>90 \%$ and iv) presence of oxygen.

If one focuses on individual test results only, definite conclusions on the functionality of the bacteria-based self-healing system cannot be drawn. Even if two out of the three performance requirements are met, they at best only indicate the efficiency of the system rather than proving full evidence. For example, $\mathrm{CaCO}_{3}$ formations on the crack surface combined with reduced crack permeability or visual crack closure after the healing treatment can also occur due to autogenous (chemical) healing. Previous studies that compare samples with and without bio-based healing agents $[2,5,6]$ have shown that crystals in partially- or fully-sealed cracks can be found also in nonbiological specimens. In fact, this behavior might exclusively originate from autogenous healing (carbonation of cement matrix) and not from bacterial healing.

Another example is when $\mathrm{CaCO}_{3}$ formations on the crack surface co-occur with bacterial activity, either from microscopic evidence of bacteria imprints, as found in this study (Fig. 3), or from oxygen consumption measurements. By combining only those two factors it cannot be claimed that this obvious 
bacterial activity will significantly reduce crack permeability. As a matter of fact, there might be biological activity and crystals but not enough to close an open crack.

Vice versa, evidence of bacterial activity combined with reduced crack permeability is very likely always accompanied by bacterial controlled mineral formation inside the crack. Yet, one needs to confirm that crack sealing is not caused, for example, by swelling of cement matrix or by impurities blocking the crack.

Therefore, all three aspects, i.e. existence of calcite formations in the crack marked by bacterial imprints, reduced crack permeability, and bacterial metabolic activity, must be studied in order to reach a conclusion for the efficiency of a bacteria-based self-healing system.

\section{CONCLUSIONS}

This paper presented the results of a study on bacteria-based self-healing mortar prisms. However, the focus was not on proving their enhanced healing behavior over mortar specimens without the healing agent. Particular emphasis was given to the three performance requirements that need to be met in order to ensure the efficiency of the bacteria-based self-healing system. It was concluded that the combination of the results that show: i) mineral formations on the surface of the crack, ii) crack sealing along with reduced permeability after cracking and iii) proof of bacterial activity can verify the efficient performance of the bacteria-based self-healing mortar.

\section{ACKNOWLEDGEMENTS}

The authors acknowledge the financial support of European Union Seventh Framework Programme (FP7/2007-2013) under grant agreement no 309451 (HEALCON), and $\mathrm{Mr}$ Arjan Thijssen for the ESEM image.

\section{REFERENCES}

[1] Stuckrath, C., Serpaell, R., Valenzuela, L.M. and Lopez, M. 2014. Quantification of Chemical and Biological Calcium
Carbonated Precipitation: Performance of Self-healing in Reinforced Mortar containing Chemical Admixtures. Cement and Concrete Composites 50: 10-15.

[2] Wiktor, V. and Jonkers H.M. 2011. Quantification of crack-healing in novel bacteria-based self-healing concrete. Cement and Concrete Composites 33: 763-770.

[3] Sierra-Beltran, M.G., Jonkers, H.M. and Schlangen, E. 2014. Characterization of Sustainable Bio-based Mortar for Concrete Repair. Construction and Building Materials 67: 344-352.

[4] Wang, J., Van Tittelboom, K., De Belie, N. and Verstraete, W. 2011. Use of Silica gel or Polyurethane Immobilized Bacteria for Self-healing Concrete. Construction and Building Materials 26: 532-540.

[5] Tziviloglou, E., Jonkers, H.M. and Schlangen, E. 2014. Bacteria-based Selfhealing Concrete to increase Liquidtightness of Cracks. In van Breugel, K. and Koenders E.A.B. (Eds.) Proceedings of: $1^{\text {st }}$ International Conference on Ageing of Materials; pp. 650-655.

[6] Tziviloglou, E., Wiktor, V., Jonkers, H.M. and Schlangen, E. 2015. Development of Bio-based Self-healing Concrete to increase Durability of Structures. In Ahmed, S.M., Xenidis, Y., Azhar, S., Smith, N.A., Yans, C.E. and Campbell S. (Eds.) Proceedings of Construction in the 21st Century. pp. 330-337.

[7] Cacchio, P., Ercole, C., Cappucio, G. and Lepidi, A. 2010. Calcium Carbonate Precipitation by Bacterial Strains Isolated from a Limestone Cave and from Loamy Soil. Geomicrobiology Journal 20:85-98.

[8] Abo-El-Enein, S.A., Ali A.H., Talkhan, F. and Abdel-Gawwad, H.A. 2012. Utilization of microbial induced calcite precipitation for sand consolidation and mortar crack remediation. HBRC Journal 8:185-92. 